\title{
How bad have fees been?
}

in more detail, for example upon support in domestic violence cases and increased poverty associated the array of welfare reforms.

Consideration was given by others to the implications of the Immigration Bill and of the new residence test. Denise McDowell of the Greater Manchester Immigration Aid Unit later addressed the conference, placing the current campaigns around immigration controls within the history of struggle in the region.

Rhona Friedman of the Justice Alliance spoke of the importance of building and maintaining unity across a wide range of community

organisations, advice providers and legal practitioners.

In concluding, the conference unanimously adopted the 'Manchester Declaration' calling inter alia for solidarity with criminal practices resisting the imminent fee cuts, information sharing, parliamentary lobbying regarding the civil legal aid changes and support for the Low Commission recommendations and their extension wherever possible.

Calls for political action in the local elections in May 2014, support for fringe meetings at the autumn party conferences and lobbying in the build up to the General Election in 2015 were also made.

A full report of this vibrant and positive conference including the 'Manchester Declaration' will be available in the near future on the website of the Greater Manchester Welfare Rights Advisers Group. John Hobson uly 2014 marks the anniversary of the introduction of fees in the employment tribunal. Few people supported them before; fewer have a good word for them now.

From the perspective of claimants, there was always something unjust about making workers pay the burden of fees when it is employers who have the deeper pockets. The Government could easily have introduced a more balanced system, for example by making claimants pay an initial issuing fee, but placing the burden on employers to decide how far they contested a claim and making them pay a hearing fee where they wanted to fight.

Trade unions also had much to lose. The tradition has been that when a trade unionist brings a claim the union pays all the costs but the worker retains the full damages. In practice, most unions have tried to keep as much of this model as they could, either paying the fees themselves or providing loans to members but in any event asking that members who succeed in their claim seek to recoup their fees and repay them to the union. The potential liability to a trade union, should any significant proportion of its members bring claims, was considerable.

Most employers' organisations were sceptical about fees, presenting them as a blunt instrument which fell just as hard on deserving as on weaker claims. There was no real belief that workers' grievances would disappear just because they were stopped from bringing tribunal claims and considerable concerns that workers would seek alternative means of redress.

A year on, we know what effect fees have had. Total claims are down by 63 per cent with group claims (typically equal pay and sex discrimination claims) down ever faster at 79 per cent.

Historically the claims which workers were most likely to win were on wages and discrimination, as the issues were simpler. It was possible for a tribunal to find for the worker without calling into question the whole running of a business. Wages claims in particular used to succeed, at least in part, in around two thirds of claims. Discrimination claims were harder to win. The effect of fees has been to obtain a much faster fall in wages and unfair dismissal claims, whereas other types of claims have held up better than the trend, race discrimination claims for example have fallen by 'only' 58 per cent. This is because fees have been set at such a high level that it makes no sense to bring an ordinary wages claim for example. The fee is just too high a proportion of the worker's potential winnings. Paradoxically therefore the claims which have seen the sharpest fall are the ones which workers were most likely to win. The policy has not discriminated against claims which are statistically weaker; rather it has discriminated against the strongest ones.

One of the Government's responses to criticisms was to introduce a 'fee remission' scheme when certain workers with low incomes and no capital would be eligible for partial or complete waiver of the tribunal fees. In the original consultation on fees, the Government estimated that 31 per cent of claimants would be eligible for fees.

After a question from Andy
Slaughter MP, the Shadow Justice Minister, the Government has announced that overall just five and a half per cent of claimants are securing the remission of their fees, either in full or in part.

The number of claims brought by trade unionists has held up far better than it has in the economy as a whole. Firms which specialise in union employment work describe a fall in the claims they issue of a mere five per cent or so, a picture which bears no comparison with the rest of the employment world.

Is it a good thing if only trade unionists can afford to bring tribunal claims in the future; won't that encourage non-members to join unions?

Before fees were introduced, a few unions attempted to estimate how much they would have to pay if their members brought claims in the same numbers as before. The general estimate was that, at $£ 1,300$ for each dismissal or discrimination claim, fees would cost unions about 10 per cent of their total annual budgets. This figure is not for their legal budgets but their budgets for every service they provided. Few unions charge more than $£ 150$ per member per year in fees and with around one in 50 workers facing dismissal each year across industry it is not difficult to see that unions simply do not have the funds to litigate post-fees without taking other steps to restrict the number of their members who can sue.

If the Government had levied a one-off 10 per cent tax on all unions there would have been uproar. This is exactly what the policy has meant in practice but without the unions yet daring to protest on a scale necessary to make the law unworkable.

\section{David Renton}

14: Tony Benn, lifelong socialist and Labour politician, dies aged 88. Tony Benn dedicated his life's work to advancing democracy and equality. He believed in solidarity and workers' rights and was outspoken in his beliefs until the end.
'In the course of my life I have developed five little democratic questions. If one meets a powerful person Adolf Hitler, Joe Stalin or Bill Gates - ask them five questions: "What power have you got? Where did you get it from? In whose interests do you exercise it? To whom are you accountable? And how can we get rid of you?' If you cannot get rid of the people who govern you, you do not live in a democratic system. Tony Benn, 22nd March 2001, final speech as MP in the House of Commons

\section{0th March 2003: US}

missiles rained down on the Iraqi capital Baghdad this day eleven years ago as the US-led war against Iraq began. Bush and Blair's war and occupation killed over one million Iraqis. 